\title{
Towards Enhancing Quality in Education through Information and Communication Technologies (ICTs) in Higher Educational Institutions (HEls)
}

\author{
Nana Yaw Asabere \\ Computer Science Department \\ School of Applied Sciences and Arts \\ Accra Polytechnic, Accra, Ghana
}

\author{
Ahmedin Mohammed Ahmed \\ Computer Science Department \\ Institute of Technology \\ Wollo University, Wollo, Ethiopia
}

\begin{abstract}
Teaching and Learning through ICT in Higher Educational Institutions (HEIs) has attracted global ICT investments of various Governments. However the results of these investments in ICT, that has a target to enhance quality of education remains to be seen and realized. Various factors such as ICT adoption and penetration, ICT infrastructure and equipment and professional development to enhance education using ICT have been limited. Using Wollo University in Ethiopia and Accra Polytechnic in Ghana as case studies, this article reviews institutional, personal and technological factors that can encourage stakeholders, teachers and students to use ICT to enhance the quality of education in these HEIs. The article reviews these factors and concludes that knowing the extent to which the enumerated barriers affect teachers and students of Wollo University and Accra Polytechnic, decisions concerning enhancing ICT quality of education through ICT can be made to the benefit of these HEIs as well as other ones.
\end{abstract}

\section{General Terms}

Information and Communication Technologies (ICTs), Education

\section{Keywords}

Adoption, Accra Polytechnic (AP), Higher Educational Institutions (HEIs), Information and Communication Technology (ICT), ICT Equipments, ICT Infrastructure, Integration, Wollo University (WU)

\section{INTRODUCTION}

The penetration of current ICT trends in education is very important and a priority for educational development and sustainability. ICT penetration in education proliferates in many different forms and most of its realization and influence has to be gained through knowledge and technical know-how. The main stakeholders of the global tertiary education industry are staff and students. The staff usually have subdivision of Senior Member, Senior Staff and Junior Staff in terms of ranking and the students are also subdivided into records such as the programmes they are pursuing, year level etc. Information and communication technologies (ICT) have become common place entities in all aspects of life. For the past twenty years the use of ICT has fundamentally changed the practices and procedures of nearly all forms of activities within business and governance. Within education, ICT has begun to have presence but the impact has not been as extensive as in other fields. Education is a very socially oriented activity and quality education has traditionally been associated with strong teachers having high degrees of personal contact with learners [1]. The use of ICT in education has introduced other modes of education other than the traditional mode. Notable ICT in education modes include Electronic Learning (E-Learning) which usually involve the use of desktop computers to teach and learn either on site or at a distance and Mobile Learning (M-Learning) which involves learning through wireless mobile devices such as mobile phone, Smartphones and Personal Digital Assistants (PDAs). ICT in education lends itself to more student-centred learning settings and often this creates some tensions for some teachers and students. But with the world moving rapidly into digital media and information, the role of ICT in education is becoming more and more important and this importance will continue to grow and develop in the 21 st century [1][2].

Table 1, illustrates and depicts some differences between Electronic Learning (E-Learning) and Mobile Learning (MLearning

Table 1. Comparison of E-Learning and M-Learning

\begin{tabular}{|l|l|l|}
\hline Comparison & E-Learning & M-Learning \\
\hline $\begin{array}{l}\text { Portability (easy to } \\
\text { carry) }\end{array}$ & $\begin{array}{l}\text { Desktop PCs } \\
\text { are not } \\
\text { portable }\end{array}$ & $\begin{array}{l}\text { Mobile Devices } \\
\text { are Portable }\end{array}$ \\
\hline Flexibility & Not Flexible & Flexible \\
\hline $\begin{array}{l}\text { Freedom of } \\
\text { Learning }\end{array}$ & $\begin{array}{l}\text { Not Anywhere } \\
\text { and Anytime }\end{array}$ & $\begin{array}{l}\text { Anywhere and } \\
\text { Anytime }\end{array}$ \\
\hline Cost of Devices & Less Expensive & More Expensive \\
\hline Cost of Technology & Less Expensive & More Expensive \\
\hline Location Education & Cannot Provide & $\begin{array}{l}\text { Can Provide } \\
\text { Through GPS }\end{array}$ \\
\hline
\end{tabular}

ICT penetration as described above proliferates in many forms such as computer availability, computer usage, internet availability, internet usage, computer literacy level and efficiency as well as ICT infrastructure. Administrators will have different uses of ICT from teachers/lecturers and students. It is therefore important to determine the ICT needs of every stakeholder in the training and tertiary institutions for comparison with the current ICT trends to suggest improvements if required [1][2]. Students may use ICT in their education depending on the mode of education adopted by the teacher/trainer involved in a particular course/programme. This paper outlines and contributes to how training institutions can enhance and improve the quality of education (teaching and learning) through ICT using Wollo University in Ethiopia and Accra Polytechnic in Ghana as case studies. The paper is organized as follows: In the Subsections of Section I, we discuss the Backgrounds and Current ICT Situations of Wollo University and Accra 
Polytechnic. In Section II we elaborate on a framework and the factors to be considered to Ensure Quality in Education Through ICT at Wollo University and Accra Polytechnic. We finally conclude the paper with a recommendation in Section III.

\subsection{Background of Accra Polytechnic (AP), Ghana and Overview of Existing/Current ICT Situation}

Accra Polytechnic started as a technical School in 1949 to train lower and middle level hands-on skilled manpower for industry. Later in 1957, it was upgraded to a Technical Institute and in 1963, renamed Accra Polytechnic by the orders of the first president of Ghana, Osagyefo Dr. Kwame Nkrumah. By the Polytechnic Law, 1992 (PNDC L321), which became fully operative in the 1993/4 academic year, Accra Polytechnic was elevated and attained a tertiary status. The institution was then placed under the Higher Education Council with an autonomous status. Notwithstanding the difficulties that characterized the quick change over from a secondary to a tertiary institution, Accra Polytechnic has made tremendous progress in its review and expansion of curriculum to suit contemporary needs [3].

New programmes and departments were created as part of the development process. Staff have been trained and re-trained to enhance their capabilities. The polytechnic law was reviewed in 2007 and mandated the institution to award degrees as well as to produce middle level manpower with the requisite hands-on experience for the needs of commerce and industry in Ghana. Thus, the Bachelor of Technology (B-Tech) degree programmes have been introduced as a new option and to give polytechnic HND graduates the opportunity to upgrade themselves. Growth over the years has enabled the polytechnic to develop and improve in infrastructure, teaching and learning facilities [3].

Presently, Accra Polytechnic offers rich curriculum in a variety of programmes and awards Higher National Diploma (HND) certificates through National Board for Professional and Technician Examination (NABPTEX), Ghana and BTech degrees. Thus, in dictates of the objectives and mission of the polytechnic, a wide range of opportunities are being provided for the Ghanaian populace and feeding of industry with the requisite skilled labour. Accra Polytechnic's vision is to become a universally acknowledged centre of excellence for Teaching and Research of applied science, arts and technology and to become a distinguished partner in the provision of Technical Vocational and Professional Skills to the manpower for the development of Ghana. Accra Polytechnic also has a mission to produce skilled career focused tertiary and middle- level manpower in the areas of manufacturing, commence, science, technology, applied social science and applied arts [3].

Accra Polytechnic has two (2) Departments relating to ICT divided into academic and non-academic. The academic department, Computer Science started which started as a Computer Unit in 1995 and metamorphosed into a Department in 2011 is responsible for all academic and research issue of the Polytechnic and trains students in the HND Computer Science programme. The computer science department manned by a Head of Department consists of lecturers and researchers in the areas of Computer Science and ICT as well as administrative staff and students. The ICT Department established in 2011 is manned by the Head of ICT, is responsible for the general operation of all ICT issues in the Polytechnic which include:
- Management and maintenance of Accra Polytechnic's Computer Laboratories.

- Provision of Internet and Email services to enhance communications, teaching, learning and research in the Polytechnic.

- Provision of network backbone connectivity - in order to access networked information resources within the Intranet of the Polytechnic (such as the MIS and Library resources) and the Internet.

- Systems Support, Maintenance and Repairs of computer hardware in all departments of the Polytechnic and installation of legal softwares.

- Provision of technical support of Polytechnic's Website and guidance in case of outsourcing.

- ICT Policy and Strategy development and implementation.

- ICT Projects Management in the Polytechnic.

- Provision of ICT Advisory Services to Polytechnic Management.

Currently Wireless Network (Wireless Fidelity (Wi-Fi)) exists in Accra Polytechnic. Both staff and students with Wi-Fi laptops have access to the internet 24-hours.

Apart from the wireless connectivity there is also access of the internet through Local Area Network (LAN) in the various offices using network cabling, switches and routers connected to a main server. Accra Polytechnic has three existing laboratories with the following statistics in terms of origination:

- Computer Laboratory 1 - $\mathbf{3 0}$ Computers

- Computer Laboratory 2-100 Computers

- Computer Laboratory 3 - $\mathbf{5 0}$ Computers

- Computer Laboratory 4 - 80 Computers

Although student population is large (approximately 11,000), subdivisions of students regarding timetabling in the computer laboratories and priority is given to students who pursue ICT related courses in a particular semester. Most staff members, especially lecturers have their own laptops for academic work and research. There are also LCD projectors installed in some classrooms for ICT lecturing delivery.

This makes a total of 260 desktop/tower computers available in computer laboratories of the Polytechnic. In training of students, the Computer Science Department tries its best to provide a one-to-one student to PC policy for students in order for students to have a better understanding during lecture sessions.

From Table 2, the current estimated number of computers in Accra Polytechnic community is 417, approximately 420. Most of the computers are equipped with Microsoft Windows XP, Vista or 7 versions and Microsoft Office 2007/2010 versions. Figure 2, shows the Wireless Access Point (AP) of Accra Polytechnic. Figures 3 and 4 depict two of the computer laboratories in Accra Polytechnic - computer availability and seating capacities respectively.

The Academic Affairs Office and Finance Office within the Administration Block of Accra Polytechnic use Topaz Software for their administrative activities/duties. There are also Antivirus Softwares installed to almost every computer in the Polytechnic, but there is a current problem of current/updated antivirus software. Most of the Antivirus Softwares in the Polytechnic are not up to date and require ICT and administrative attention. 


\begin{tabular}{|c|c|c|}
\hline S/N & DEPARTMENT/BLOCK & $\begin{array}{c}\text { NUMBER OF } \\
\text { COMPUTERS } \\
\text { (PCs) }\end{array}$ \\
\hline 1 & Administration Block & 63 \\
\hline 2 & Library Block (N) & 8 \\
\hline 3 & Accountancy Block (K) & 6 \\
\hline 4 & $\begin{array}{c}\text { Science Laboratory Tech. } \\
\text { Block }\end{array}$ & 6 \\
\hline 5 & $\begin{array}{c}\text { Mechanical Engineering } \\
\text { Block }\end{array}$ & 13 \\
\hline 6 & Examination Block & 3 \\
\hline 7 & Catering Block & 10 \\
\hline 8 & Electrical Engineering Block & 8 \\
\hline 9 & $\begin{array}{c}\text { Bachelor of Technology } \\
\text { Block }\end{array}$ & 30 \\
\hline 10 & Fashion Block & $\underline{417}$ \\
\hline 11 & Computer Laboratories & TOTAL \\
\hline & T & \\
\hline
\end{tabular}

Table 2. Estimated Number of Computers in Accra Polytechnic, Ghana

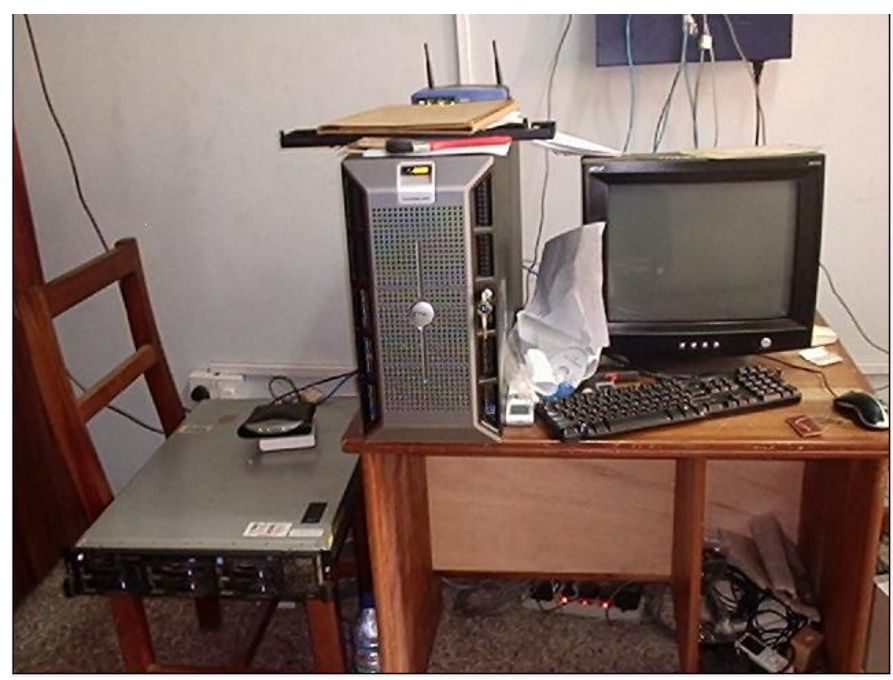

Fig. 1: Main Server Room of Accra Polytechnic, Ghana

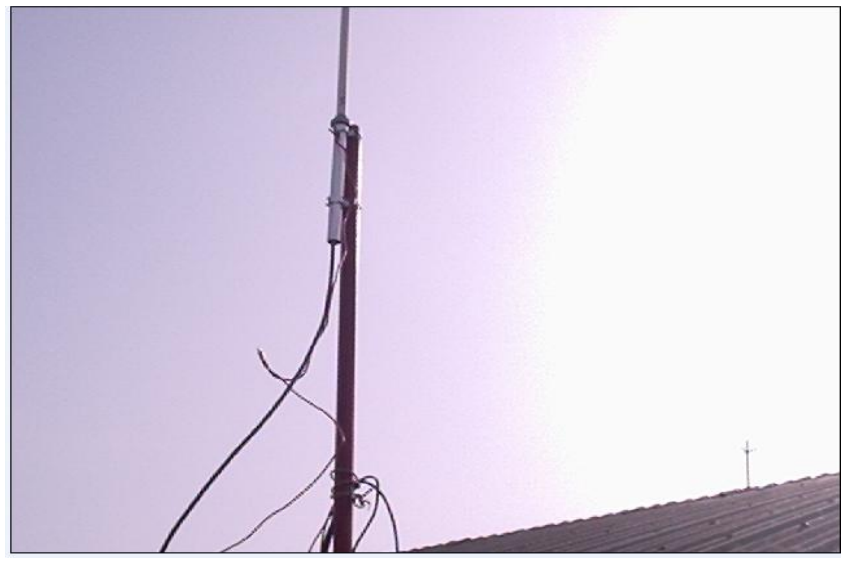

Fig. 2: Wireless AP, Accra Polytechnic, Ghana

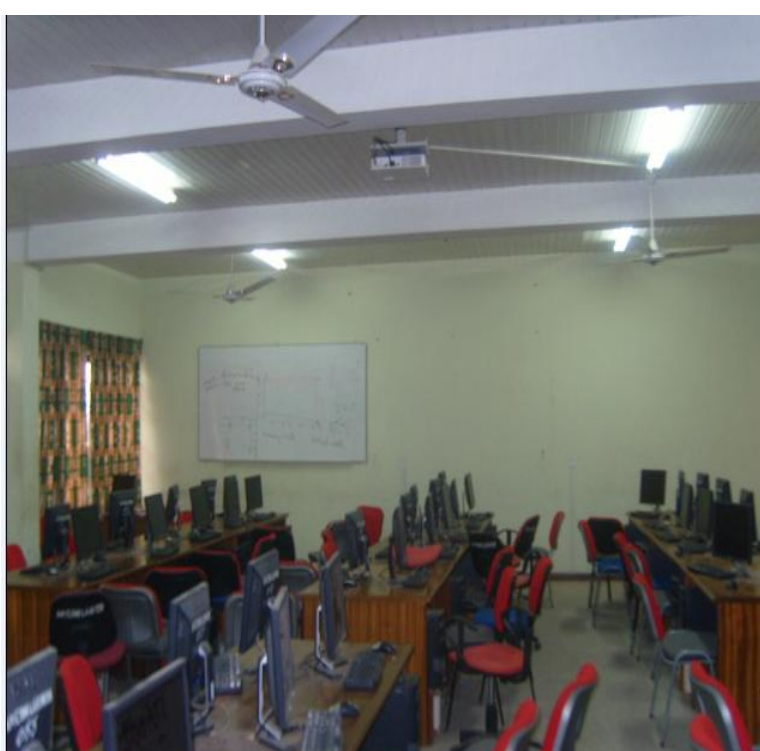

Fig. 3: Computer Laboratory 2, 50 Computers/Seating Capacities

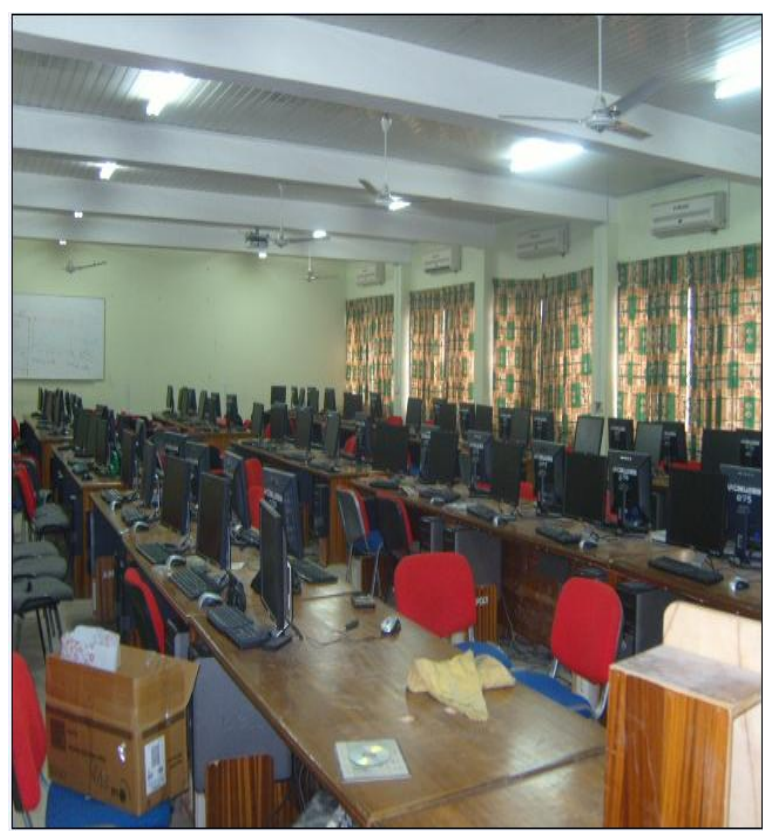

Fig. 4: Computer Laboratory 3, Accra Polytechnic -100 Computers/Seating Capacities

1.2 Background of Wollo University (WU), Ethiopia and Overview of Existing/Current ICT Situation

Within its overall plan of alleviating wide spread poverty, Ethiopia aims to become a middle level income country within a short period of time, but there is a shortage of skilled professionals. To further ensure sustainable growth, improve livelihoods to take the place in the global economy, Wollo University (Formerly - Dessie Kombolcha University) is looking to build the capacity in order that, in future, it will be able to train a large number of quality graduates in various disciplines.

There is also the need to put in place a system \& culture of quality university management \& administration. Specifically, the government is planning to further expand access to higher 
education through expanding and strengthening the former universities and by opening new universities in various parts of the country. Wollo University is one of the thirteen new universities started its operations in March 2007. The mission of Wollo University (WU) [4] as public University is to contribute to the intellectual, economic and social development of our society. Wollo University is committed to prepare students for further academic and professional education and for employments in various sectors of the economy in the country. The mission of Wollo University can be stated specifically as: To maintain standards of academic excellence essential to our students' future success and to provide appropriate programmes, services and technology to ensure that any student admitted has the opportunity to develop the skills necessary to achieve these standards; Continue to develop innovative and flexible educational approaches to serve the needs of the students; Affirm that the University, as a community, requires the participation and representation of all its members /students, staff and faculty/ in its governance; Encourage the personal and social development of Wollo University students through activities outside the classroom; Develop the role of the University as a community resource and as a center of for life-long learning; Be engaged in local, regional and federal social and economic development for the benefits of both the public and private sectors. Offer consultancy and applied research services.

Wollo University has three (3) academic Departments (Computer Science, Information Technology and Information Systems) relating to ICT and one ICT Development Office as an administrative section having two branches in each campus, namely Dessie Campus and Kombolcha Campus and other ICT units. While the three departments are responsible for the academic issues, the ICT Development Office was established around 2007 through visionary leadership of a few individuals who realized that Wollo University would be wise to join the information age by adopting the technology that has been transforming the world. The ICT Development Office (ICTDO) at WU which has been in existence for about 5 years under various designations and has played the lead role in the adoption and use of ICT at the university. In particular, it has been the entity that has initiated and managed the build-out of the university network infrastructure.

The ICTDO is staffed with a number employees headed by the ICT Development Officer, and then Director of ICT and Library who reports to the Vice President and President of the university. In spite of its lead role in the development, deployment, and management of ICT at the university, however, the ICTDO has yet to be incorporated into the permanent university governance structure. As a result, its mandate has yet to be clearly defined. The office does not have an ICT budget and funds most of its activities through donor money/funding. There has also been an absence of an ICT policy to govern the acquisition and use of ICT at the university. The development of ICT resources for higher education is a fruitful context to involve the university community in the improvement of their own resources, not only building capacities, but also strengthening collaborative networks among key actors.

The Association of University Students for Cooperation (AUCOOP), from the Polytechnic University of Catalonia (UPC, Spain), was established in 2007 with the aim to participate in international cooperation projects related to technological areas [5].

AUCOOP started in Ethiopia in 2009, and for the last 3 years it has been working with Wollo University on different projects related to the development of ICT resources on higher education. During the year 2010/11, a Telecommunication
Degree Final Project (UPC) was conducted in Wollo University, building the relationships between the two institutions. In 2011, seminars were given related to wireless technology, digital content applications, and active methodologies with the use of Moodle. Modular ObjectOriented Dynamic Learning Environment (MOODLE) [6] is a free source e-learning software platform, also known as a Course Management System, Learning Management System, or Virtual Learning Environment (VLE). From these initiatives, a Master student from Addis Ababa University decided to implement his Master's Project related to the development of digital content tools taking the case study of Wollo University, which is currently underway. Later, during 2012, two grade students from Wollo University also started their degree project on network resources, with the possibility to include their results as part of an overall development of ICT resources at Wollo University.

Currently, LAN and wireless internet access exists in Wollo University. There have been agreements with Ethiopian Telecom Cooperation (ETC) to provide both campuses of the University with high speed and reliable internet accesses through better and enhanced ICT resources. However, these kinds of ICT resources needs time to be developed, and also collaboration from all the people in Wollo University, that is, teachers, students and all staff members. The ICT team members are doing their best to achieve a well-developed ICT Center to provide useful and efficient services to the community.

\section{QUALITY OF EDUCATION ENHANCEMENT IN HEIS}

Enhancement of the quality of education through ICT requires integration of ICT by training and tertiary institutions and adoption of ICT usage by teachers and students/learners. We describe the concept of adoption in accordance to literature as the decisions that individuals make each time that they consider taking up an innovation [7]. Rogers [8] defines adoption as the decision of an individual to make use of an innovation as the best course of action available. Earle [9] cited by Buabeng-Andoh [1] linked ICT integration with the concept of wholeness, when all elements of the system are connected together to become a whole. For instance, the two important elements of teaching and learning which are content and pedagogy must be joined when technology is used in lesson. In another way, if students are offered series of websites or ICT tools (e.g. CD ROMs, multimedia, etc.) then the teacher is not integrating ICT into teaching since he/she is not tackling the pedagogical issues. Similarly, Williams [10] described ICT integration as the means of using any ICT tool (Internet, e-learning technologies, CD ROMs, etc.) to assist teaching and learning. For the purpose of this research paper/study, we will adopt Williams' definition of ICT integration. Training and tertiary institutions have to adopt a framework that ensures quality in education using ICT initially through teachers. Sherry \& Gibson [11] developed a framework for effective strategies for the stages of learning/adoption of technology by teachers. We discuss and elaborate more on this framework below in Table 3. As enumerated below in Table 3, several factors influencing the adoption and integration of ICT into teaching and learning have been identified by researchers.

Stockdill and Moreshouse [12] identified user characteristics, content characteristics, technological considerations, and organizational capacity as factors influencing ICT adoption and integration into teaching and learning. Sherry \& Gibson 
[11] observed and discussed that technological, individual, when examining ICT adoption and integration.

Rogers [8] identified five technological characteristics or attributes that influence the decision to adopt a technological innovation. Neyland [13] identified factors such as institutional support as well as micro factors such as teacher organizational, and institutional factors should be considered capability influencing the use of online learning in high schools in Sydney, Australia. Sherry \& Gibson [11] also identified that technological, individual and institutional factors are to be considered for the integration and adoption of ICT in teaching and learning in training institutions.

Table 3. Effective Strategies for the Stages of Learning/Adoption of ICT by Teachers for Quality in Education Source: Sherry \& Gibson (2002)

\begin{tabular}{|c|c|c|}
\hline Developmental Stage & Development Process & Effective Strategies \\
\hline Stage 1 & $\begin{array}{l}\text { Teacher as a Learner } \\
\text { Stage } 1 \text { is the information- } \\
\text { gathering stage. To ensure quality } \\
\text { in education, teachers of tertiary } \\
\text { and training institutions have to } \\
\text { learn the knowledge and skills } \\
\text { necessary for performing } \\
\text { instructional tasks using } \\
\text { technology. }\end{array}$ & $\begin{array}{l}\text { Time for training; demonstrations of promising practices; ongoing } \\
\text { professional development by peers rather than one-shot workshops by } \\
\text { outside experts; in-service sessions that stress the alignment of } \\
\text { technology with curriculum and standards. } \\
\text { Consideration of the following related factors: Personal } \\
\text { Characteristics, Professional Development of Teachers, Computer } \\
\text { Literacy and ICT Competence and ICT/Computer Self-efficacy. }\end{array}$ \\
\hline Stage 2 & $\begin{array}{l}\text { Teacher as an Adopter } \\
\text { In stage 2, teachers' progress } \\
\text { through stages of personal and } \\
\text { task management concerns, as } \\
\text { they experiment with the } \\
\text { technology and begin to try it out } \\
\text { in their classrooms, and share } \\
\text { their experiences with their peers. }\end{array}$ & $\begin{array}{l}\text { Online resources. Help desks and other forms of readily accessible } \\
\text { technical support. Mechanisms to deal with technical problems as they } \\
\text { arise; in-building technical specialists; other technology-savvy teachers } \\
\text { who can mentor new users and provide them with care and comfort as } \\
\text { well as information. Open lab workshops at school sites to solve } \\
\text { specific technical problems. } \\
\text { Consideration of the following related factors: Accessibility of } \\
\text { Computers and ICT Facilities/Infrastructure, Technical Support, } \\
\text { Teaching Experience, Teacher Workload, and ICT/Computer Self- } \\
\text { efficacy, Gender }\end{array}$ \\
\hline Stage 3 & $\begin{array}{l}\text { Teacher as a Colearner } \\
\text { In this stage, teachers focus on } \\
\text { developing a clear relationship } \\
\text { between technology and the } \\
\text { curriculum, rather than } \\
\text { concentrating on } \\
\text { management aspects. }\end{array}$ & $\begin{array}{l}\text { Workshops and online resources with strategies for enhancing } \\
\text { instruction and integrating technology into the curriculum. Collegial } \\
\text { sharing of standards integration; exemplary products and assessment } \\
\text { ideas; use of students as informal technical assistants. } \\
\text { Consideration of the following related factors: Teaching Experience, } \\
\text { Teacher Workload, ICT/Computer Self-efficacy, Computer Literacy } \\
\text { and ICT Competence, and ICT/Computer Self-efficacy, Gender. }\end{array}$ \\
\hline Stage 4 & $\begin{array}{l}\text { Teacher as Reaffirmer or } \\
\text { Rejecter: } \\
\text { In this stage, teachers develop a } \\
\text { greater awareness of intermediate } \\
\text { learning outcomes. They begin to } \\
\text { create new ways to observe and } \\
\text { assess impact on student products } \\
\text { and performances, and to } \\
\text { disseminate exemplary student } \\
\text { work to a larger audience. }\end{array}$ & $\begin{array}{l}\text { Administrative support; an incentive system that is valued by adopting } \\
\text { teachers. Awareness of intermediate learning outcomes such as } \\
\text { increased time on task, lower absenteeism, greater student } \\
\text { engagement, and increased metacognitive skills; evidence of impact on } \\
\text { student products and performances; dissemination of exemplary } \\
\text { student work. } \\
\text { Consideration of the following related factors: Institutional } \\
\text { Characteristics Teachers' Attitudes \& ICT Teaching Delivery } \\
\text { Acceptance, Teaching Experience, Teacher Workload, Personal } \\
\text { Characteristics }\end{array}$ \\
\hline Stage 5 & $\begin{array}{l}\text { Teacher as } \\
\text { In this stage, experienced teachers } \\
\text { expand their roles to become } \\
\text { active researchers who carefully } \\
\text { observe their practice, collect } \\
\text { data, share the improvements in } \\
\text { practice with peers, and teach new } \\
\text { members. Their skills become } \\
\text { portable. }\end{array}$ & $\begin{array}{l}\text { Incentives for co-teaching onsite workshops; release time and other } \\
\text { semi-permanent role changes to allow peer coaching and outside } \\
\text { consulting. Support from an outside network of teacher-leaders; } \\
\text { structured time for leading in-house discussions and workshops. } \\
\text { Transfer of skills if teacher goes to another school. } \\
\text { Consideration of the following related factors: Institutional } \\
\text { Characteristics, Leadership and Management Support, Professional } \\
\text { Development, Teaching Experience and Gender }\end{array}$ \\
\hline
\end{tabular}


Through literature review, we adopt the framework of Sherry $\&$ Gibson [11] on how to enhance the quality of education through ICT by considering technological, individual and institutional factors in the use of ICT by teachers and learners. Quality of education enhancement through ICT is important and requires the adoption and integration of ICT in tertiary/training institutions without any disadvantageous influences or obstacles. The factors that should be considered by Wollo University and Accra Polytechnic include:

\subsection{Institutional Characteristics}

The Institutional characteristics of Wollo University and Accra Polytechnic help to improve teachers' existing attributes. According to Vannatta \& Fordham [14], teacher's time committed to teaching and amount of technology training are reliable factors of technology use in classroom. Vannatta \& Fordham [14] asserted that teacher trainers and administrators should not only "provide extensive training on educational technology, but should also facilitate a contribution to teaching improvement".

Therefore Wollo University and Accra Polytechnic should observe institutional characteristics pertaining to ICT integration and adoption so as to promote teaching and learning through ICT. Norris et al. [15] also pointed out to the importance of access to technology for effective adoption and integration by training institutions. Therefore, an understanding of institutional characteristics will influence teachers' adoption and integration of using ICT in teaching delivery.

\subsection{Personal Characteristics}

According to Schiller [16] personal characteristics such as educational level, age, gender, educational experience, experience with the computer for educational purpose and attitude towards computers can influence the adoption of a technology. Teachers are implored to adopt and integrate ICT into teaching and learning activities, but teachers' preparedness to integrate ICT into teaching determines the effectiveness of the technology and not by its sheer existence in the classroom [17]. The attitudes of teachers towards technology greatly influence their adoption and integration of computers into their teaching. According to Russell and Bradley [18], anxiety, lack of confidence and competence and fear often implies ICT takes a back seat to conventional learning mechanisms. Therefore, an understanding of personal characteristics that influence teachers' adoption and integration of ICT into teaching is relevant and important. Teachers and trainers of Wollo University and Accra Polytechnic require personal characteristic capabilities that are technologically inclined in order to integrate and adopt ICT for teaching students in their respective institutions. In the same notion, students/learners of Accra Polytechnic and Wollo University must also have technological personal characteristics in order to corroborate technological teaching methods of teachers. Without technologically inclined personal characteristics of both teachers and students in Wollo University and Accra Polytechnic, enhancement of quality education through ICT will be very difficult.

\subsection{Teachers' Attitudes and ICT Teaching Delivery Acceptance}

Apart from personal characteristics of teachers, it is also important for teachers and trainers of tertiary/training institutions to have ICT teaching attitudes and delivery acceptance. To successfully initiate and implement educational technology in school's program depends strongly on the teachers' support and attitudes. It is believed that if teachers perceive technology programmes as neither fulfilling their needs nor their students' needs, it is likely that they will not integrate the technology into their teaching and learning [1].

If teachers' in Wollo University and Accra Polytechnic have positive attitudes and acceptance towards ICT teaching delivery and the use of educational technology then they can easily provide useful insight about the adoption and integration of ICT into teaching and learning processes. Lack of positive teacher attitudes towards using ICT for teaching in Wollo University and Accra Polytechnic will seek to reduce and diminish ICT adoption and integration for teaching and hence also reduce enhancement of quality education in these institutions through ICT. Hence teacher's attitudes and their acceptance of ICT for teaching delivery should be tackled by Wollo University and Accra Polytechnic.

\subsection{Teaching Experience}

There is a saying that experience is the best teacher. Though some research have reported that teachers' experience in teaching did not influence their use of computer technology in teaching [19], most research have showed that teaching experience influences the successful use of ICT in classrooms [20][21][22]. A report by Gorder [23] discussed that teacher experience is significantly correlated with the actual use of technology. In her study, she revealed that effective use of computer was related to technological comfort levels and the liberty to shape instruction to teacher-perceived student needs. Also, Baek et al. [24] argued that experienced teachers are less ready to integrate ICT into their teaching as compared to less experienced teachers. Furthermore, a report by the United States National Centre for Education Statistics [25] revealed that teachers with less experience in teaching were more likely to integrate computers in their teaching than teachers with more experience in teaching. According to the report in [25], teachers with up to three years teaching experience reported spending $48 \%$ of their time utilizing computers, teachers with teaching experience between 4 and 9 years, spend $45 \%$ of their time utilizing computers, teachers with experience between 10 and 19 years spend $47 \%$ of the time, and finally teachers with more than 20 years teaching experience utilize computers $33 \%$ of their time. The reason to this disparity may be that fresh teachers are more experienced in using the technology or more technologically inclined.

As stated and cited above, new teachers are likely to be more technologically inclined and will use ICT to teach due to the recent and current proliferation of ICT. Teachers with more experience may not be conversant with using ICT for teaching, since technology had not proliferated to the level it is now when they started teaching. As a result of such scenarios, Wollo University and Accra Polytechnic should organize ICT related seminars, conferences or workshops to encourage teachers who are experienced in teaching but don't teach without ICT to improve their pedagogy by using current ICT tools and facilities to teach. Teachers who are also experienced in using ICT to teach should also be encouraged to attend such seminars, conferences or workshops so that they can be educated more in using ICT to improve their pedagogy.

\subsection{Teacher Workload}

Many teachers in most institutions are used to scheduling their time to teach without an ICT influence in their teaching procedure. Many studies have revealed that the workloads of 
teachers influence their acceptance of technology in classrooms. For example, Samarawickrema \& Stacey [26] investigated factors related to the use of learning management system in a large multi-campus urban university in Australia. They adopted case study method and purposive sampling to select 22 participants used web-based methods to teach both on- and off- campus students for the study. The findings of the research in [26] found that increased workload coupled with teaching with technology was critical to the participants of the study.

Factors reported to contribute to increased workload were course maintenance and constant upgrades, student e-mails, the learning of new skills and the continuous search of sustainable strategies. The workloads of teachers in Wollo University and Accra Polytechnic are high and adoption and integration of teaching activities to teacher's current workload will be impractical if teachers don't exhibit the required pedagogy to integrate and adopt ICT in their teaching. For example a teacher in Wollo University or Accra Polytechnic deciding to use ICT as part of his/her teaching should instruct his/her students to submit assignments only electronically through e-mail instead of combining both manual and electronic submissions which will create too much teaching load an inappropriate time used in assessments and evaluations.

\subsection{Professional Development of Teachers}

Teachers' professional development is a key factor to successful integration of ICT in teaching. Several research studies in [27]-[29], have revealed that whether beginner or experienced, ICT related training programmes develop teachers' competences in computer and ICT usage and influence teachers' attitudes towards computers. ICT related training programmes also assist teachers to reorganize the task of technology and how new technological tools are significant in student learning, so that related technology training can be successfully integrated in the classroom [30]-[32].

Professional development of teachers through ICT related training programs should be encouraged by Wollo University and Accra Polytechnic for sustainability of the enhancement of quality education using ICT.

\subsection{Computer Literacy and ICT Competence} Enhancement of quality education through ICT requires both teachers and students to be computer literate and ICT competent. Computer literacy and ICT competence is defined as being able to handle a wide range of varying computer applications for various purposes [1]. Wollo University and Accra Polytechnic would require teachers who have computer skills and are computer literate as well as ICT competent.

To achieve a high competency level in these institutions, teachers who don't have computer skills and are not ICT competent have to be trained through ICT related seminars and workshops by experts in the field of ICT. When teachers have the required training of ICT, they can impart their ICT knowledge to students/learners who are also not computer literate and ICT competent.

\subsection{ICT/Computer Self-Efficacy}

After a teacher becomes computer literate, gains computer skills and also becomes ICT competent, the next important factor is for teachers to have a strong ability, confidence and agility to use ICT for teaching delivery, which can be referred to as ICT/Computer self-efficacy. Research that has been conducted on teacher's self-efficacy has shown reports and results of greater effect on their use of ICT. Self-Efficacy is defined as a belief in one's own abilities to perform an action or activity necessary to achieve a goal or task [33]. Generally, self-efficacy is the confidence that an individual has in his/her ability to do the things that he/she strives to do. Thus teachers' confidence in ICT refers to both the teachers' perceived likelihood of success on using ICT for educational purposes and on how far the teacher perceives success as being under his or her control in ICT usage [34].

According to Liaw et al. [35], teachers' computer self-efficacy influences their use of ICT in teaching and learning. It is therefore important that ICT/Computer Self-Efficacy is demonstrated by teachers after being trained on how to use ICT for teaching delivery. Teachers and students of Wollo University and Accra Polytechnic should be encouraged to gain ICT/Computer Self-Efficacy in order to improve and enhance quality of education using ICT.

\subsection{Gender}

As part of the ICT policies in both Wollo University and Accra Polytechnic, there should be an "ICT Usage for ALL" policy. This means that whether teachers are males or females they should all be encouraged to use ICT to teach and there should not be any discriminations or discrepancies in relation to gender. Gender differences and gender inequality involved in the use of ICT have been reported in several studies. Some of the studies concerning teachers' gender and ICT use have cited the low levels of computer usage by female teachers' are due to their limited technology access, skill, and interest [36]. Research studies in [29][37] revealed that male teachers used more ICT in their teaching and learning processes than their female counterparts. Furthermore, Markauskaite [38], investigated gender differences in self-reported ICT experience and ICT literacy among first year graduate trainee teachers. The study revealed significant differences between males and females in technical ICT capabilities, situational and longitudinal sustainability. Such discrepancies and scenarios should not be encouraged in Wollo University and Accra Polytechnic. Both males and females teachers of Wollo University and Accra Polytechnic should have equal opportunities for the usage of ICT to teach and female teachers should be encouraged more if there is a case in which ICT usage by female teachers to teach is relatively low.

\subsection{Accessibility of Computers and ICT Facilities/Infrastructure}

Access to ICT infrastructure and resources in schools is a necessary condition for the integration of ICT in education [39]. Effective adoption and integration of ICT into teaching in schools, mainly depends on the availability and accessibility of ICT resources such as hardware, software, etc. Obviously, if teachers cannot access ICT resources, then they will not use them.

As shown from previous Section I of this paper, the current/existing ICT situations of Wollo University and Accra Polytechnic show the presence of computers, ICT facilities and infrastructure which encourages ICT adoption and integration.

Computer laboratories should be fully and further equipped with modern ICT computing and ICT facilities and teachers should also get support from institutions to buy personal laptops that they can use to facilitate teaching. LCD projectors should also be available in computer laboratories and classrooms for effective ICT teaching delivery and learning. ICT network infrastructure for Wollo University and Accra Polytechnic should be improved in accordance to the capacity and size of the bandwidth in order to meet yearly increasing 
students and teacher/worker population. Access to computers, ICT, updated software and hardware are therefore key elements to successful adoption and integration of technology for teaching and learning in Higher Educational Institutions (HEIs).

\subsection{Technical Support}

The availability of computers and ICT in Wollo University and Accra Polytechnic requires technical support of the computers, ICT equipment, facilities and infrastructure. Break down of computers or malfunction of ICT infrastructure and facilities retards the enhancement of quality education through ICT. Without adequate technical support, teachers will effectively be discouraged from using computers because of fear of equipment failure. Therefore, if there is no technical support for teachers, they become frustrated resulting in their unwillingness to use ICT to teach students [40].

As a consequence, Wollo University and Accra Polytechnic should have an educational objective of making sure that there is enough technical support for computers and ICT equipments in their respective institutions, in order to meet the required ICT needs of teachers and students.

\subsection{Management and Leadership Support}

Without the support from management, board and councils of Wollo University and Accra Polytechnic, ICT adoption and integration is almost impossible. Support of these stakeholders is required for successful ICT integration and adoption in order to enhance quality education through ICT. Yee [41] believes that a leader who implements technology plans and also shares a common vision with the teachers and students to stimulate them in their lessons. Initial management and leadership support of ICT adoption and integration is important for Wollo University and Accra Polytechnic.

Leaders and management of Wollo University and Accra Polytechnic should also not discourage enhancement of quality education through ICT but rather encourage it.

\section{Conclusion and Recommendation}

The rapid increase and proliferation of technologies has complicated its adoption and integration by teachers in classrooms of training and tertiary institutions with Wollo University and Accra Polytechnic not being an exception. Using current technologies in training and tertiary institutions requires encouragements of adoption, integration and onward involvement of the technological tools and facilities. Effectively integrating technology into classroom practices poses more challenges to teachers, students and institutions as compared to connecting computers to a network and setting up a computer laboratory.

For successful integration of ICT into teaching for enhancement of quality education, this paper through relevant literature has outlined and highlighted on factors that positively or negatively influence teachers' use of ICT in training and tertiary institutions.

This paper recommends that Wollo University and Accra Polytechnic as well as all other training institutions in developing countries should embark on tasks to integrate ICT in their institutions for teaching and learning. When embarking on these tasks, related factors consisting of teacher, personal and institutional characteristics as well as other factors enumerated in this paper should be tackled and solved for onward implementation.

\section{References}

[1] C. Buabeng-Andoh "Factors Influencing Teachers' Adoption and Integration of Information and Communication Technology into Teaching: A Review of the Literature" International Journal of Education and Development using Information and Communication Technology (IJEDICT), 2012, Vol. 8, Issue 1, pp. 136155, 2012.

[2] R. Oliver "The Role of ICT in Higher Education for the 21st Century: ICT as a Change Agent for Education", Proceedings of the Higher Education for the 21st Century Conference. Miri, Sarawak: Curtin University, 2002.

[3] Accra Polytechnic, Ghana, Retrieved From: www.apoly.edu.gh on 08/09/2012.

[4] Wollo University, Ethiopia, Retrieved From: www.wu.edu.et on 10/07/2012.

[5] The Association of University Students for Cooperation (AUCOOP), Retrieved From: http://www.esunet.uji.es/archives/254_on 11/09/2012.

[6] Modular Object-Oriented Dynamic Learning Environment (MOODLE) Retrieved From: http://en.wikipedia.org/wiki/Moodle_on 25/09/2012.

[7] A. Rangaswamy and S. Gupta "Innovation Adoption and Diffusion in the Digital Environment": Some Research Opportunities, 2000.

[8] E.M. Rogers "Diffusion of innovations" New York: Free Press, 2003.

[9] R.S. Earle "The Integration of Instructional Technology into Public Education: Promises and Challenges". ET Magazine, Vol. 42, no. 1, pp. 5-13, 2002.

[10] M. D. Williams "Technology Integration in Education" In Tan, S.C. \& Wong, F.L. (Eds.), Teaching and Learning with Technology, pp. 17-31: An Asia-pacific Perspective. Singapore: Prentice Hall, 2003.

[11] L. Sherry and, D. Gibson "The Path to Teacher Leadership in Educational Technology", Contemporary Issues in Technology and Teacher Education, Vol. 2, No. 2, pp. 178-203, 2002.

[12] S.H.Stockdill and D. L. Morehouse "Critical Factors in the Successful Adoption of Technology: A Checklist Based on the Findings", Educational Technology, Vol. 32, No. 1,pp.57-58, 1992.

[13] E. Neyland "Integrating Online Learning in NSW Secondary Schools: Three Schools Perspectives on ICT Adoption", Australia Journal of Educational Technology, Vol. 27, No. 1, pp. 152-173, 2011.

[14] R. Vannatta and N. Fordham "Teacher Dispositions as Predictors of Classroom Technology Use". Journal of Research on Technology in Education, Vol. 36, No. 3, pp. 253-271, 2004.

[15] C. T. Norris, J. Sullivan, Poirot and E. Soloway "No Access, no use, no Impact: Snapshot Surveys of Educational Technology in K-12, Journal of Research on Technology in Education, Vol. 36, No. 1, pp. 15-27, 2003. 
[16] J. Schiler "Working with ICT: Perceptions of Australian Principals, Journal of Educational Administration, Vol. 41, No. 3, pp. 171-185, 2003.

[17] C.A. Jones "Teach Support: Preparing Teachers to use Technology”. Principal Leadership, Vol. 1, No. 9, pp. $35-39,2001$

[18] G. Russell and G. Bradley "Teachers' Computer Anxiety: Implications for Professional Development". Education and Information Technologies, Vol. 2, pp.1730, 1997.

[19] D.S. Niederhauser and, T. Stoddart "Teachers' Instructional Perspectives and use of Educational Software". Teaching and Teacher Education, vol. 17, pp.15-31, 2001.

[20] E.M.L. Wong and S.C. Li "Framing ICT Implementation in a Context of Educational Change: A Multilevel Analysis". School Effectiveness and School Improvement, 19(1), 99-120, 2008

[21] V. Giordano "A Professional Development Model to Promote Internet Integration into P-12 Teachers' Practice: A mixed Method Study. Computers in the schools, Vol. 24, No.3/4, pp.111-123, 2007.

[22] P. Hernandez-Ramos "If not here, Where? Understanding Teachers use of Technology in Silicon Valley Schools. .Journal of Research on Technology in education, Vol. 38, No.1, pp. 39-64, 2005.

[23] L. M. Gorder "A Study of Teacher Perceptions of Instructional Technology Integration in the Classroom". Delta Pi Epsilon Journal, Vol. 50, No. 2, pp. 63-76, 2008.

[24] Y.G. Baek, J. Jong and B. Kim "What Makes Teachers use Technology in the Classroom? Exploring the Factors Affecting Facilitation of Technology with a Korean Sample". Computers and Education, Vol.50, No. 8, pp. 224-234, 2008

[25] U.S. Department of Education - National Center for Education Statistics "Teachers' Tools for the 21st Century": A Report on Teachers' use of Technology, 2000.

[26] G. Samarawickrema and E. Stacey "Web-based Learning and Teaching: A Case Study in Higher Education". Distance Education, Vol. 28, No. 3, pp. 313-333, 2007.

[27] J. Bauer and J. Kenton "Toward Technology Integration in the Schools: Why it isn't Happening", Journal of Technology and Teacher Education, Vol. 13, No. 4, pp. 519-546, 2005.

[28] C. Franklin "Factors that Influence Elementary Teachers use of Computers". Journal of Technology and Teacher Education, Vol. 15, No. 2, pp. 267-293, 2007.
[29] L. Wozney, V. Venkatesh and P.C Abrami "Implementing Computer Technologies: Teachers' Perceptions and Practices". Journal of Technology and Teacher Education, Vol. 14, No.1, pp. 173-207, 2006.

[30] K. F. Hew and T. Brush "Integrating Technology into K-12 Teaching and Learning: Current Knowledge Gaps and Recommendations for Future Research", Educational Technology Research and Development, Vol. 55, pp. 223-253, 2007.

[31] J. Keengwe and G. Onchwari "Computer Technology Integration and Student Learning Barriers and Promise", Journal of Science Education and Technology, Vol. 17, pp. 560-565, 2008.

[32] J. Mueller, E. Wood, T. Willoughby, C. Ross and J. Specht "Identifying Discriminating Variables Between Teachers who Fully Integrate Computers and Teachers with Limited Integration”, Computers \& Education, Vol. 51, No. 4, pp. 1523-1537, 2008.

[33] A. Bandura "Self-Efficacy: The Exercise of Control", New York: Freeman, 1997.

[34] H. Peralta and F.A. Costa "Teachers' Competence and Confidence Regarding the use of ICT". Educational Sciences Journal, Vol. 3, pp. 75-84, 2007.

[35] S. Liaw, H. Huang and G. Chen "Surveying Instructor and Learner Attitudes Towards E-learning", Computers \& Education, Vol. 49, No. 4, pp. 1066-1080, 2007.

[36] M. Volman and E. van Eck "Gender Equity and Information Technology in Education: The Second Decade", Review of Educational Research, Vol. 71, No 4, pp. 613-634, 2001.

[37] R. Kay "Addressing Gender Differences in Computer Ability, Attitudes and Use: The Laptop Effect". Journal of Educational Computing Research, Vol. 34, No. 2, pp. 187-211, 2006

[38] L. Markauskaite "Gender Issues in Preservice Teachers" Training: ICT Literacy and Online Learning". Australasian Journal of Educational Technology, Vol. 22, No. 1, pp. 1-20, 2006.

[39] T. Plomp, R. E. Anderson, N. Law and A. Quale (Eds.) "Cross-national Information and Communication Technology: Policies and Practices in Education". Charlotte, N.C.: Information Age Publishing, 2009.

[40] K.P Tong and S.G. Triniada "Conditions and Constraints of Sustainable Innovative Pedagogical Practices Using Technology", Journal of International Electronic for leadership in learning, Vol. 9, No.3, pp. 1-27, 2005.

[41] D. L. Yee "Images of School Principals' Information and Communication Technology Leadership". Technology, Pedagogy and Education, Vol. 9, No. 3, 2000 